\title{
KONTESTASI ELIT DAN MARGINALISASI PENDUDUK LOKAL DI LOKASI GALIAN C DESA SEBUDI-KARANGASEM
}

\author{
I Wayan Tagel Eddy \\ Prodi Sejarah Fakultas Ilmu Budaya Universitas Udayana \\ Tageleddy58@gmail.com
}

\begin{abstract}
ABSTRAK
Konstitusi negara Republik Indonesia mengamanatkan bahwa, air, bumi, dan kekayaan alam dikuasai oleh negara dan digunakan sebesar-besarnya untuk kemakmuran rakyat. Namun dalam prakteknya jauh berbeda, pengelolaan kekayaan alam, khususnya galian $\mathrm{C}$ tidaklah semudah yang dibayangkan dalam konsep teoretis, banyak kepentingan yang ada di baliknya. Alih-alih memikirkan kepentingan masyarakat, pemerintah justru membiarkan pengelolaan itu kepada pihak pengusaha luar (investor). Kontestasi politik terjadi tidak hanya antara penguasa/pemerintah dengan pengusaha/korporasi tetapi juga dengan warga lokal. Tulisan ini akan mencoba menjelaskan fenomena kontestasi dan marginalisasi yang terjadi di Desa Sebudi-Karangasem.

Selama ini studi galian C lebih banyak menyuguhkan fakta dan data tentang konflik, dimana wilayah SebudiKarangasem dikonstruksi sebagai wilayah penuh konflik dan masyarakatnya sulit diajak berdamai. Masyarakat Sebudi ditempatkan sebagai objek yang diam dan miskin inisiatif, sehingga memerlukan intervensi dari luar, melalui kebijakan pemerintah. Untuk menjelaskan fenomena ini, digunakan teori konflik dan konsensus dari Ralph Dahdrenrof (Ritzer, 2009) yang menyatakan setiap masyarakat mempunyai potensi konflik, tetapi kemampuan menemukan konsensus adalah jalan untuk menciptakan keseimbangan sosial (harmoni). Secara metodologis, tulisan ini menggunakan pendekatan kualitatif, sehingga deskripsi terhadap fenomena yang tampak di Desa Sebudi dapat diinterpretasi dan dimaknai secara lebih baik.
\end{abstract}

Kata Kunci: kontestasi, marginalisasi, kapitalisme, galian C

\section{LATAR BELAKANG}

Konstitusi negara Indonesia mengamanatkan bahwa bumi, air serta kekayaan yang terkandung di dalamnya dikuasai oleh negara dan diperuntukkan sebesar-besarnya untuk kesejahtraan rakyat. Amanat konstitusi ini sejalan dengan prinsip dasar sosialisme demokrasi yang membuka ruang seluas-luasnya bagi intervensi negara dalam upaya mengelola kekayaan alam demi kemakmuran rakyatnya. Dengan demikian setiap kebijakan pemerintah yang berhubungkait dengan kekayaan alam harus bersifat populis yang menekankan pada distribusi hasil kekayaan bagi pemegang kedaulatan yaitu rakyat. Akan tetapi dalam kenyataannya berbeda jauh, pengelolaan kekayaan alam yang berupa galian $\mathrm{C}$ tidaklah sesederhana yang dibayangkan, banyak kepentingan bermain di belakangnya. Alih-alih memikirkan kepentingan rakyat, pemerintah justru membiarkan pengelolaan galian $\mathrm{C}$ itu kepada pihak pengusaha luar (investor) sehingga terjadi kontestasi politik antara pemerintah, pengusaha dan juga warga lokal (warga Desa Sebudi).

Selama ini studi tentang usaha galian $\mathrm{C}$ lebih banyak menyuguhkan fakta dan data tentang konflik, dimana Desa Sebudi Karangasem dikonstruksi sebagai wilayah penuh konflik dan masyarakatnya sangat sulit diajak berdamai. Masyarakat Desa Sebudi ditempatkan sebagai objek yang diam dan miskin inisiatif, sehingga membutuhkan intervensi dari pihak luar, khususnya melalui kebijakan pemerintah.

Terkait dengan adanya kegiatan eksplorasi galian C di Desa Sebudi Karangasem, maka pemerintah mulai mengeluarkan regulasi berupa Peraturan Daerah Provinsi Daerah Tingkat I Bali Nomor 7 Tahun 1995 tentang izin usaha pertambangan bahan galian golongan $\mathrm{C}$ (Lembaran Daerah Provinsi Daerah Tingkat I Bali 158 Tahun 1996 Seri B Nomor 3), dan dilanjutkan dengan dikeluarkannya Peraturan Pemerintah Daerah Tingkat II Kabupaten Karangasem No. 1 Tahun 1998 tentang Pajak Pengambilan dan Pengolahan Bahan Galian Golongan C (Lembaran Daerah Kabupaten Daerah Tingkat II Kabupaten Karangasem Nomor 7 Tahun 1988 Seri A No. 1). Berdasarkan atas kedua peraturan ini, galian $\mathrm{C}$ di Kabupaten Karangasem mulai dibuka secara resmi. Dibukanya usaha galian C di Desa Sebudi, telah menunjukkan adanya intervensi pemerintah 
atas rakyatnya secara hegemonk untuk meminjam istilah dari Gramsci (Takwin, 2009:72).

Masyarakat Desa Sebudi mulai terjebak dalam hegemoni usaha Galian C sehingga sektor potensial yang dimiliki masyarakat seperti peternakan, pertanian mulai beralih fungsi dan mereka telah beubah status yang semula sebagai petani atau peternak kini menjadi buruh di usaha galian C. Desa Sebudi benar-benar menjadi tempat hunian dan sekaligus arena pertarungan para aktor yang memburu material Galian C, atmosfir Desa Sebudi penuh dengan wacana di seputar isu galian C. Barang milik alam ini telah menjadi teks dan praktik kebudayaan yang sarat dengan nuansa ekonomi. Menjamurnya usaha galian C di Desa Sebudi ternyata tidak berbanding lurus dengan tingkat kesejahtraan penduduk setempat. Penduduk di sekitar lokasi usaha galian $\mathrm{C}$ kurang menikmati hasil usaha galian $\mathrm{C}$, hasilnya lebih banyak dinikmati oleh para pengusaha luar (investor) dan jajaran pejabat daerah. Bahkan masyarakat di sekitar galian $\mathrm{C}$ semakin termarginalisasikan baik secara sosial maupun kultural. Semangat kebersamaan yang menjadi modal sosial bagi tatanan kehidupan warga Desa Sebudi scara harmonis, kini semakin memudar karena terkikis arus kapitalisasi yang kian menyeruak. Desa Sebudi adalah salah satu desa yang terletak di lereng kaki Gunung Agung, Kecamatan Selat, Kabupaten Karangasem merupakan sebuah panggung kontestasi perebutan usaha galian C. Berbagai aktivitas politik dan ekonomi bahkan kultural adalah sebuah manifestasi kontestasi untuk meraih rejeki (Bali Post, 30 Desember 2012).

Di kalangan elite desa, usaha galian $\mathrm{C}$ adalah komoditas tambang yang bagaimanapun harus dieksplorasi untuk meningkatkan pendapatan daerah. Para petinggi di jajaran birokrasi menempatkan galian $\mathrm{C}$ sebagai barang strategis yang bernilai ekonomi tiggi oleh karena itu harus dikelola dan dikuasai. Segenap regulasi harus dibuat agar galian $\mathrm{C}$ dapat dieksplorasi dan dijual. Tidak penting apakah di masa mendatang akan membawa kehidpan atau risiko negative, yang penting adalah bagaimana agar galian $\mathrm{C}$ dikuasai dan digali secara besar-besaran untuk kemudian dijual. Oleh karena itu pemerintah Kabupaten Karangasem membiarkan kepada pengusaha untuk mengesplorasi galian $\mathrm{C}$ tanpa ada negosiasi kritis bahwa galian $\mathrm{C}$ akan bisa berakibat rusaknya lingkungan alam, termasuk dampak sosial-budayanya.
Eksplorasi atas sumber daya alam dalam bentuk usaha galian $\mathrm{C}$ kurang memperhatikan kelestarian lingkungan. Usaha galian C di Desa Sebudi selama tahun 2011 hingga 2012 menurut Data base Provinsi Bali ada empat lokasi usaha galian C yang illegal, sedang Nusa Bali.com (27 Mei 2016) melaporkan ada 11 usaha galian $C$ yang illegal. Adanya dominasi pemerintah yang mengatur masyarakat melalui wacana-wacana yang tersembunyi di balik kekuasaan, terutama penerbitan regulasi tentang eksplorasi galian $\mathrm{C}$ menyebabkan masyarakat lokal akan terperangkap secara normatif ke dalam jebakan-jebakan halus yang kurang berpihak pada kepentingan masyarakat lokal. Hal ini terjadi karena adanya ideologi kepentingan yang berbeda dan pada akhirnya akan menimbulkan kontestasi antara pemerintah, pengusaha dan masyarakat yang tinggal di sekitar usaha galian $\mathrm{C}$ tersebut. Relasi transaksional atas dasar perbedaan kepentingan tampak berkontribusi memicu terjadinya kontestasi, negosiasi dalam eksplorasi galian $\mathrm{C}$ di Desa Sebudi baik antara pemerintah, pengusaha maupun dengan warga lokal.

\section{PEMBAHASAN}

\section{Aktor Kontestasi}

Ada beberapa faktor dalam kontestasi memperebutkan usaha galian C. Pertama, pemerintah baik provinsi maupun kabupaten; pengusaha (investor), politisi, aparat keamanan, tokoh masyarakat,ormas, dan warga masyarakat. Semuanya berupaya menunjukkan eksistensinya manakala berurusan dengan usaha galian $\mathrm{C}$, dan tentu saja di antara mereka saling berkontestasi berebut rejeki di galian C. Pemerintah melalui Kementerian Energi dan Sumber Daya Mineral (ESDM), mengklaim mempunyai kewenangan utama dalam kepemilikan galian $\mathrm{C}$, sehingga siapapun yang ingin mengelola usaha galian $\mathrm{C}$ harus berurusan dengan pemerintah pusat. Oleh karena itu hasil usaha galian $\mathrm{C}$ sebagian harus diambil pemerintah pusat. Sementara itu pemerintah daerah baik provinsi juga menjadi kontestan perebutan galian C. Dengan mengklaim sebagai tanah wilayahnya, maka siapapun yang ingin membuka usaha galian $\mathrm{C}$ harus seizin pemerintah daerah.

Meskipun sama-sama aktor dari kalangan pemerintah, di antara mereka juga berkontestasi . Misalnya terkait dengan persoalan retribusi usaha 
galian $\mathrm{C}$, hingga sekarang masih saling tarikmenarik kepentingan antara pemerintah provinsi dan pemerintah kabupaten. Pemerintah Kabupaten Karangasem merasa memiliki wilayah yang kaya dengan kandungan material pasir dan koral, tetapi kurang memberikan kontribusi signifikan terhadap APBD. Karena itu berdasarkan UU Nomor 23 Tahun 2014 tentang Pemerintahan Daerah, bahwa segala urusan pemerintahan di bidang energi dan sumber daya mineral termasuk pertambangan batuan (galian C) menjadi kewenangan daerah provinsi (Bali Post, 4 Maret 2018).

Hal ini diperkuat lagi dengan surat Kementerian ESDM Nomor 04.E/30/DJB/2015 dalam poin 5 huruf $\mathrm{c}$ dan $\mathrm{d}$, disebutkan bahwa dalam rangka pelaksanaan kewenangan Pemerintah Provinsi di bidang pertambangan mineral dan batubara, gubernur diminta untuk segera memproses penetapan wilayah pertambangan rakyat, dan memproses permohonan (izin) yang diajukan pemohon (Rekomendasi DPR Provinsi Bali kepada Gubernur Bali). Pembuatan peraturan oleh pemerintah Kabupaten Karangasem juga merupakan cara untuk memperebutkan kue galian C. Ketika berkontestasi dengan pemerintah provinsi, mereka bertarung untuk mendapatkan restribusi galian C. Sementara kontestasinya dengan para pengusaha galian $\mathrm{C}$, dengan "senjata" perda revitalisasi lingkungan dan ekosistem yang layak sebagai tanah perkebunan, adalah cara untuk mendapatkan bagian kue usaha galian $\mathrm{C}$ dengan menekan para pengusaha galian $\mathrm{C}$.

Harus diakui bahwa niat awal Pemerintah Kabupaten Karangasem menerbitkan berbagai produk hukum, seperti Perda dan SK Bupati misalnya bertujuan untuk mengatur tata kelola usaha galian $\mathrm{C}$ demi kepentingan kesejahtraan rakyat, dan sekaligus peduli pada pelestarian lingkungan hidup. Munculnya peraturan-peraturan itu sebagai responsatas munculnya masalah ketidaktertiban dan ketidakpedulian usaha galian C terhadap lingkungan hidup. Akan tetapi Perda semacam itu jika dicermati secara teliti merupakan modus elite pemerintah untuk berebut rejeki usaha galian $\mathrm{C}$. Ada celah yang digunakan untuk memeras para pengusaha galian $\mathrm{C}$ sehingga menjadi pintu masuk untuk mengaksesrejeki galian C. Jadi modusnya dengan cara menjual pasal-pasal yang berisi sanksi atau ancaman kepada pengusaha, tetapi sekaligus membuka ruang untuk "negosiasi".
Sudah menjadi rahasia umum bahwa makna negosiasi di sini adalah bersifat transaksional. Karena itu persoalan Amdal misalnya, akan dengan mudah menjadi ajang permainan negosiasi yang ujung-ujungnya adalah uang dengan perinsip tahu sama tahu. Umum mengetahui juga jika kalangan birokrat pemerintahan berelasi dengan para pengusaha galian $\mathrm{C}$, menjadikan segenap produk hukum sebagai komoditas untuk memperoleh keuntungan. Teks peraturan memiliki kandungan kekuasaan, yaitu berupa ketentuan sah untuk memaksa para pihak yang dikenai peraturan. Ranah ini akan dimanfaatkan oleh birokrat yang memiliki kekuasaan untuk menutup perusahaan atau ijin dicabut jika melanggar aturan yang sejak awal sulit dipenuhi.

Tidak disadari bahwa teks Perda adalah amanat rakyat, mengingat proses pembuatannya melalui perdebatan di lembaga perwakilan rakyat. Dalam hal ini mandat rakyat diselewengkan demi kepentingan bisnis. Yang mendapat untung adalah penguasa, dan bukan rakyat biasa yang merupakan pemilik sah atas kekayaan alam. Pada saat proses pembuatan regulasi, para penguasa mengatasnamakan rakyat dengan menerapkan politik representasi, namun setelah menjadi produk resmi, dimanfaatkan menjadi komoditas. Perda adalah sebuah teks yang syarat dengan muatan kekuasaan, dan sekaligus berpotensi menjadi sumber untuk meraih keuntungan ekonomi.

Aktor lain adalah para pengusaha (investor) yang sejak semula berkepentingan untuk mengeksplorasi galian $\mathrm{C}$ di Desa Sebudi. Sejumlah pengusaha galian $\mathrm{C}$ satu sama lain berkontestasi dalam berbagai bentuk, dan adakalanya mengalami gesekan kepentingan. Tarik menarik kepentingan antara sejumlah pengusaha dengan segenap elemen masyarakat juga merupakan aktor kontestasi dalam upaya memperebutkan usaha galian C. Dengan kata lain usaha galian C di Desa Sebudi terus bertarung dan berhadapan dengan sejumlah elemen masyarakat selama mereka berproduksi. Eksistensi galian C itu sendiri sejak awal sudah merupakan eksistensi kontestatif.

Pada saat pengusaha galian $\mathrm{C}$ berhadapan dengan warga lokal, perusahaan harus siap dengan sejumlah tuntutan warga yang semuanya bersifat transaksional. Sejak ramainya usaha galian $\mathrm{C}$ di Desa Sebudi, denyut lalu lintas di jalan menuju ke arah desa Sebudi dan sekitarnya dengan 
banyaknya hilir-mudik truk dalam frekuensi tinggi, warga mulai merasa terganggu kebisingan serta tebaran debu yang berakibat pada kesehatan, sehingga masalah ini menimbulkan konflik antara pihak pengusaha dengan warga masyarakat sekitar. Menariknya adalah bahwa solusi yang ditawarkan bukan lagi menggunakan mekanisme kultural dengan mengedepankan musyawarah, tetapi berubah pada hubungan transaksional dengan "menjual" masalah gangguan yang ditimbulkan oleh perusahaan galian $\mathrm{C}$ itu, sehingga muncul istilah "uang bising", "uang debu" dan uang-uang lainnya lagi.

Sejumlah aktor lain pun kemudian bermunculan mengikuti pergeseran hubungan kultural menjadi hubungan transaksional tersebut. Sejumlah organisasi massa, organisasi adat pun bermunculan mengakumulasikan daya tawar lokal, yaitu klaim warga "asli" dan "jumlah anggota banyak" yang perlu juga mendapat perhatian dari pengusaha galian C di Desa Sebudi, dengan alasan bahwa usaha galian $\mathrm{C}$ adalah pengeruk kekayaan alam dan banyak uang dan cara semacam itu merupakan cara yang paling efektif bagi warga untuk memperoleh bagian dari pengurasan kekayaan sumber daya alam bumi di Desa Sebudi Karangasem.

\section{Termarginalnya warga lokal}

Mengapa di tengah eksplorasi besarbesaran atas galian $\mathrm{C}$, penduduk sekitar kurang mendapat akses meraih keuntungan? Salah satu faktor penyebabnya adalah karakter usaha galian $\mathrm{C}$ bersifat padat modal. Untuk menggali galian $\mathrm{C}$ diperlukan peralatan berat seperti esvakator, buldoser, dan alat transfortasi bersekala besar. Di samping memerlukan modal besar, karakter usaha galian $\mathrm{C}$ kurang menyerap tenaga kerja yang berasal dari penduduk setempat. Untuk mengoperasikan sejumlah peralatan utama, diperlukan latar belakang pendidikan yang memadai, dan skill tinggi. Mengingat penduduk sekitar kurang memiliki sumber daya manusia yang memadai, maka tenaga kerja lokal sulit terserap pada sektor usaha galian $\mathrm{C}$ kecuali beberapa jenis pekerjaan yang mengandalkan otot, seperti buruh angkut, dan tenaga keamanan yang daya serapnya sedikit. Akibatnya pendduk Desa Sebudi kurang terangkat kesejahtraannya, dan tetap berada dalam kondisi termarginalkan.

Kondisi semacam itu membuat penduduk sekitar praktis hanya menjadi penonton di tengah hiruk pikuknya eksploarsi galian C. Mereka berada dalam deru mesin alat berat dan lalu lalang angkutan truk yang besar. Mereka begitu akrab dengan situasi gairah dan semaraknya usaha galian $\mathrm{C}$, namun secara struktural terhalang pembatas yang tidak memungkinkan mengakses rejeki dari galian $\mathrm{C}$ secara lebih beradab. Hanya dengan mengandalkan rasa memiliki wilayah dan kemudian menggertak perusahaan secara kolektif dalam bentuk protes pada momen tertentu yang merugikan masyarakat lokal. Hanya dari aktivitas itulah penduduk lokal diharapkan bisa mendapatkan rejeki dari usaha galian $\mathrm{C}$, dan bukan melalui cara-cara yang lebih beradab seperti bekerja di sektor usaha galian $\mathrm{C}$ yang mengandalkan skill serta memiliki pengetahuan yang memadai. Akibat ketidak mampuannya ini lah maka warga lokal telah mengalami marginalisasi di wilayahnya sendiri, ibarat ayam mati di dalam lumbung padi.

\section{Perlawanan warga lokal}

Di tengah semaraknya para pengusaha mengeksplorasi galian $\mathrm{C}$ yang aktor utamanya adalah para pengusaha, pemerintah dan aparat keamanan, telah terjadi proses peminggiran dan bahkan pemiskinan secara struktural (kemiskinan struktural). Hanya para aktor yang potensial yang mendapatkan rejeki dalam kontestasi perebutan galian C di Desa Sebudi. Sementara warga lokal kebanyakan kurang mendapatkan peluang untuk meraup rejeki dari usaha galian $\mathrm{C}$, akibat keterbatasan Sumber Daya Manusia dan batasbatas struktural sebagai konstruksi elite yang berkolaborasi dengan kekuatan kapital. Jawaban atas keadaan seperti itu, meskipun dalam bentuknya yang vulgar mendapat perlawanan atau resistensi dari para warga lokal. Bentuk resistensi itu antara lain melakukan penghadangan pada sejumlah truk yang mengangkut pasir, protes atas pencemaran lingkungan dan kebisingan.

Ada juga bentuk perlawanan berupa penolakan terhadap eksplorasi galian $\mathrm{C}$, dan harus dihentikan karena tidak membawa kemakmuran bagi warga Desa Sebudi.Protes semacam ini biasanya dilakukan warga atas pendampingan LSM. Akan tetapi sebegitu jauh protes keras ini tidak mendapat tanggapan serius dari perusahaan galian C, karena kaum kapitalis mendapat dukungan dari kalangan birokrat dan aparat keamanan. Lebih dari itu, perekonomian Desa Sebudi sudah sangat tergantung pada sektor galian 
C. Oleh karena itu sejumlah protes warga lokal terhadap usaha galian $\mathrm{C}$ sering mengalami kegagalan, dan sebagai kompensasinya adalah membayar dalam bentuk uang. Ironisnya cara semacam itu berjalan efektif, dan perlawanan warga di sekitar galian $\mathrm{C}$ praktis tidak ada karena memang kurang memiliki kesadaran bahwa mereka terpinggirkan oleh kehadiran aktivitas galian C.

Sejumlah Lembaga Swadaya Masyarakat (LSM) berupaya untuk menyadarkan mereka akan keterpinggirannya, namun usahanya itu kurang berhasil, dan bahkan beberapa LSM melakkan politik representasi. Artinya tidak sedikit yang melakukan advokasi atas nama warga penduduk sekitar, tetapi pada akhirnya hanya demi kepentingan mereka sendiri, dan bahkan demi ikut meraih rejeki juga pada galian $C$. sementara Pemerintah Kabupaten Karangasem juga melakukan politik representasi dengan membuat sejumlah peraturan seperti SK Bupati atau Perda. Dalam setiap konsideran dan tujuan produk hukum itu senantiasa melindungi dan demi upaya kesejahtraan warga sekitar galian $\mathrm{C}$, namun pada praksisnya tidak demikian adanya. Produk hukum itu sendiri lebih digunakan sebagai instumen birokrat untuk mendapatkan keuntungan dari usaha galian $\mathrm{C}$ itu sendiri.

\section{PENUTUP}

Dari apa yang diuraikan di atas, dapat disimpulkan bahwa sejumlah aktor bermain dalam panggung kontestasi yang semuanya berawal pada usaha bagaimana mendapatkan bagian rejeki dari usaha galian C. JIka dicermati proses distribusi rejeki galian $\mathrm{C}$, baik secara langsung maupun tidak langsung, ternyata sangat tidak merata. Terutama bagi warga sekitar galian C, kurang mendapatkan akseshasil galian $\mathrm{C}$ akibat adanya kendala struktural maupun kultural. Situasi ini menimbulkan ironi di tengah gemilang kekayaan alam galian $\mathrm{C}$ yang depositnya sangat tinggi, namun di Desa Sebudi tampak masih banyak warga yang hidupnya berada di bawah garis kemiskinan.

Di tengah kenyataan seperti itu, tampak negara tampil lemah, karena tidak mampu menjadikan galian $\mathrm{C}$ menjadi sebesar-besarnya untuk kemakmuran rakyat sebagaimana diamanatkan dalam UUD 1945. Salah satu sebabnya karena negara menjadi bagian dari kontestasi memperebutkan rejeki galian $\mathrm{C}$.
Negara, dalam hal ini pemerintah Kabupaten Karangasem mengalami individualisasi dan personalisasi, sehingga sejumlah produk negara dalam bentuk Perda atau pun ketentuan resmi digunakan sebagai instrumen efektif dalam meraih keuntungan pribadi.

Perda pun mengalami komodifikasi ketika birokrasi berelasi dengan kalangan kapitalis galian C. Birokrasi tidak berusaha mengefektifkan tata kelola eksplorasi galian $\mathrm{C}$ dengan perinsip demi kepentingan public, tetapi mengubahnya demi kepentingan segelintir elit birokrat, politisi, aparat keamanan, melalui peme liharaan hubungan transaksional. Berkaitan dengan itu pula, aparat keamanan pun ikut bermain dalam panggung kontestasi perebutan rejeki galian $\mathrm{C}$ dengan "menjual" jasa keamanan.

Di tengah-tengah hiruk pikuknya kontestasi perebutan galian C di Desa Sebudi Karangasem, denyut perekonomian Desa Sebudi pada umumnya memang terasa menguat. Akan tetapi ironisnya, di tengah gelimang uang galian $\mathrm{C}$, warga masyarakat sekitar masih banyak yang miskin. Lebih dari itu, apa pun yang terjadi dalam aktivitas galian $\mathrm{C}$, tetapi satu hal yang jelas bahwa kerusakan alam tak terhindarkan. Ekosistem Desa Sebudi terkoyak, terkelupas, dan merana di tengah ambisi dan mesin hasrat kapitalisme yang tak pernah terpuaskan.

\section{DAFTAR PUSTAKA}

\section{ATURAN PERUNDANG-UNDANGAN}

Keputusan Bupati Karangasem Nomor 385 Tahun 2000 tentang Pajak Penghasilan dan Pengelolaan Bahan Galian Golongan C dalam Lembaran Daerah Kabupaten Karangasem Tahun 2000, Nomor 27 Lembaga Daerah Kabupaten Daerah Tingkat II Kabupaten Karangasem No. 7 Tahun 1988 Seri A No. 1.

Peraturan Daerah Provinsi Daerah Tingkat I Bali Nomor 7 Tahun 1995 tentang Izin Usaha Pertambangan Bahan Galian Golongan C dalam Lembaran Daerah Provinsi Daerah Tingkat I Bali 158 Tahun 1996 Seri B, Nomor 3.

Peraturan Pemerintah Daerah Tingkat II Kabupaten Karangasem Nomor 1 Tahun 1998 tentang Pajak Pengambilan dan Pengeloaan Bahan Galian $\mathrm{C}$ dalam 
Lembaran Daerah Tingkat II Karangasem Nomor 7 Tahun 1988 Seri A No. 1.

Peraturan Pemerintah Republik Indonesia Nomor 27 Tahun 1980 tentang Penggolongan Bahan-Bahan Galian dalam Lembaran Negara Republik Indonesia 1980 No. 47.

\section{SURAT KABAR}

Anonim, "Parah kerusakan Lingkungan di Karangasem”, Bali Post, 21 Juni 2010

, "Buka 24 Jam: Galian C Rawan Jadi Tempat Pelacuran", Bali Post, 27 April 2011.

, "Bali Dibiarkan Bopeng: Kaki Gunung Agung Dikeruk", Bali Post, 30 Desember 2012.

, "Tangani Galian C Ilegal Polisi Diminta Tak Tebang Pilih", Bali Post, 8 Agustus 2014.

-, "Galian C yang tak Putus Dirundung Masalah: Pemkab Tak Sanggup Cegah Kebocoran Pajak", Bali Post, 30 Juni 2016
"Seluruh Usaha Galian C Sebudi Ilegal", Bali Post, 18 Oktober 2017.

---------, "Kekisruhan Pengambilan Pasir di Galian C Berujung Sopir Saling Hadang", Jawa Post 7 Maret 2018.

\section{BUKU-BUKU}

Barker, Chris. 2009. Cultural Studies: Teori dan Praktik. Yogyakarta: Kreasi Wacana.

Giddens, Anthony.1991. Modernity and SelfIdentity: Self and Society in the Late Modern Age. Stanford California: Standford University Press.

Helmi. 2013. Hukum Perizinan Lingkungan Hidup. Yogyakarta: Graha Ilmu.

Sutrisno, Mudji., et al., 2005. Teori-Teori Kebudayaan. Yogyakarta: Kanisius.

Setyowati, Agnes. 2019. Cultural Studies: Sebuah Pengantar, Teori, dan Konsep. Jakarta: Mitra Wacana Media. 